\title{
Application of GIS for the identification and demarcation of selective heavy metal concentrations in the urban groundwater
}

\author{
Sobia ASHRAF ${ }^{1}$, ${ }^{*}$ Farhat ABBAS ${ }^{1}$, Muhammad IBRAHIM ${ }^{1}$, Umer RASHID ${ }^{2}$, \\ Shoaib KHALID ${ }^{3}$, Hammad Raza AHMAD ${ }^{4}$, Khalid Rehman HAKEEM ${ }^{5}$, \\ Tahir MAJEED ${ }^{6}$
}

1. Department of Environmental Sciences and Engineering, Government College University, Faisalabad (38000), Pakistan;

2. Institute of Advanced Technology, Universiti Putra Malaysia, UPM Serdang 43400, Selangor, Malaysia;

3. Department of Geography, Government College University, Faisalabad 38000, Pakistan;

4. Institute of Soil \& Environmental Sciences, University of Agriculture, Faisalabad 38040, Pakistan;

5. Faculty of Forestry, University of Putra Malaysia, Serdang 43400, Selangor, Malaysia;

6. Institute of Soil Chemistry and Environmental Sciences, Ayub Agricultural Research Institute (AARI), Jhang Road, Faisalabad

\begin{abstract}
Groundwater is the most appropriate and widely used source of drinking water, which is increasingly threatened by pollution from industrial and agricultural activities. To check the severity of the problem, 156 groundwater samples were collected from various depths (60-110 ft) of 52 different localities in Faisalabad city, the third largest metropolis in Pakistan, and analyzed for the metals ( $\mathrm{Zn}, \mathrm{Cu}, \mathrm{Cd}, \mathrm{Ni}, \mathrm{Pb}, \mathrm{Mn}$ and Fe) concentration in 2009. Quantification was done by using Flame Atomic Absorption Spectrophotometer technique and the results were compared with WHO standards for drinking water quality. Results showed that the levels of $\mathrm{Cu}, \mathrm{Mn}$ and Fe were below the WHO standards while the concentrations of $\mathrm{Zn}, \mathrm{Cd}, \mathrm{Ni}$ and $\mathrm{Pb}$ were above the recommended levels of safe drinking water. Correlation analysis among the occurrence of these heavy metals revealed a highly significant and positive correlation of $\mathrm{Mn}$ with $\mathrm{Zn}$ and $\mathrm{Fe}$. A significant and positive correlation of $\mathrm{Cd}$ was also found with $\mathrm{Cu}$ and groundwater depth showing that there is strong association between $\mathrm{Cu}-\mathrm{Cd}$ pair and that the $\mathrm{Cd}$ concentration varies with depth of groundwater in the study area. Regional patterns of heavy metals occurrence were mapped using Geographical Information System (GIS) for the identification and demarcation of risk areas. The concentration maps may be used by policymakers of the city to mitigate groundwater pollution.
\end{abstract}

Keywords: heavy metals; groundwater contamination; Faisalabad; pollution mitigation

\section{Introduction}

Water is one of the essentials that support all forms of life on earth and is a finite commodity

Received: 2014-01-27 Accepted: 2014-05-15

*Corresponding author: Farhat Abbas, E-mail: farhat@gcuf.edu.pk;

The fourth author: Umer RASHID, E-mail: umer.rashid@yahoo.com 
on the globe. Safe drinking water is a fundamental human right and is essential for the protection of public health and environment. Only $2.8 \%$ of the total water on earth is fresh water; the rest is in the form of salt water. Some $75 \%$ of the fresh water is frozen as the glaciers and icecaps. Thus, less than $1 \%$ of the total water that is present in rivers and underground resources is available to meet our present day requirements (Prasad and Narayana, 2004).

Groundwater is the most appropriate and widely used source of drinking water, which is increasingly threatened by pollution from industrial and agricultural activities. The natural water deterioration is an emerging environmental issue throughout the world. The problems become acute where natural pollutants are intensified by anthropogenic activities (Ahmad et al., 2004). The groundwater pollution is mainly caused by disposing of industrial effluents directly into the nearby drains, rivers, streams, ponds, ditches and open fields or agricultural lands (Ullah et al., 2009). Metals are discharged to groundwater by untreated wastes from industries, traffic, municipal wastes, hazardous waste sites, agricultural fields and accidental oil spillages from tankers (Igwilo et al., 2006). The metals and metal ions thus discharged into the environment (soil and water) may enter into the food chain and affect the health of plants and animals (Ahmad et al., 2008; Ahmad et al., 2010; Fardous et al., 2010; Ahmad et al., 2011; Rehman et al., 2013). The movement of different metal and ions in soil is under the influence of various soil related properties (Ibrahim et al., 2012). These metals need to be removed from the media (Irfan et al., 2013).

Studies have been carried out upon the quality of groundwater in terms of heavy metal concentrations in different cities of Pakistan including Peshawar (Ilyas and Sarwar, 2003), Skardu (Lodhi et al., 2003), Kasur (Tariq et al., 2008), Islamabad (Kausar and Zulfiqar, 2009), Sialkot (Ullah et al., 2009), Lahore (Akhter et al. , 2010), Tando Allahyar (Majidano and Khuwahar, 2009), Dera Ismail Khan (Ahmad and Anwar, 2011) and Kohistan (Said et al., 2011). No study was carried out in the near past in Faisalabad city on a large scale except one at small scale (Rashid et al., 1996).

Keeping in view the importance of potable water and associated hazardous effects of trace metal ions, the present study was conducted to assess the quality status of groundwater from different localities in Faisalabad city, the third largest metropolis in Pakistan, with the following specific objectives: (i) to assess and map the quality of groundwater with respect to heavy metal ( $\mathrm{Zn}, \mathrm{Cu}, \mathrm{Cd}, \mathrm{Ni}, \mathrm{Pb}, \mathrm{Mn}$ and $\mathrm{Fe}$ ) concentration and compare it with WHO standards for drinking water quality, and (ii) to analyze correlation among the occurrence of these heavy metals.

\section{Materials and methods}

Groundwater samples from motor driven pumps at different depths ranging from 60 to $110 \mathrm{ft}$ were collected for analysis of metal concentration ( $\mathrm{Zn}, \mathrm{Cu}, \mathrm{Cd}, \mathrm{Ni}, \mathrm{Pb}, \mathrm{Mn}$, and $\mathrm{Fe}$ ) in December 2009. Grab representative 156 groundwater samples in triplicates were collected randomly from 52 different localities of Faisalabad city area. Samples were collected in pre-cleaned $500 \mathrm{ml}$ polyethylene bottles. During the collection of groundwater samples special emphasis was given to the localities where groundwater was the only source of drinking water. Groundwater samples collected from each locality were plotted on the street map of 
Faisalabad city. Site identification was marked on Faisalabad city map. Figure 1 shows the major localities of Faisalabad city and the groundwater sampling sites.

\subsection{Analysis of heavy metal and GIS mapping}

Atomic Absorption Spectrophotometer (Model: Varian Spectra AA 250 Plus) with air-acetylene based method was used for the determination of heavy metals in water. ArcGIS version 10.0 was used to map the heavy metals concentration in groundwater from different urban areas of Faisalabad city. It is fullfeatured GIS software for visualizing,

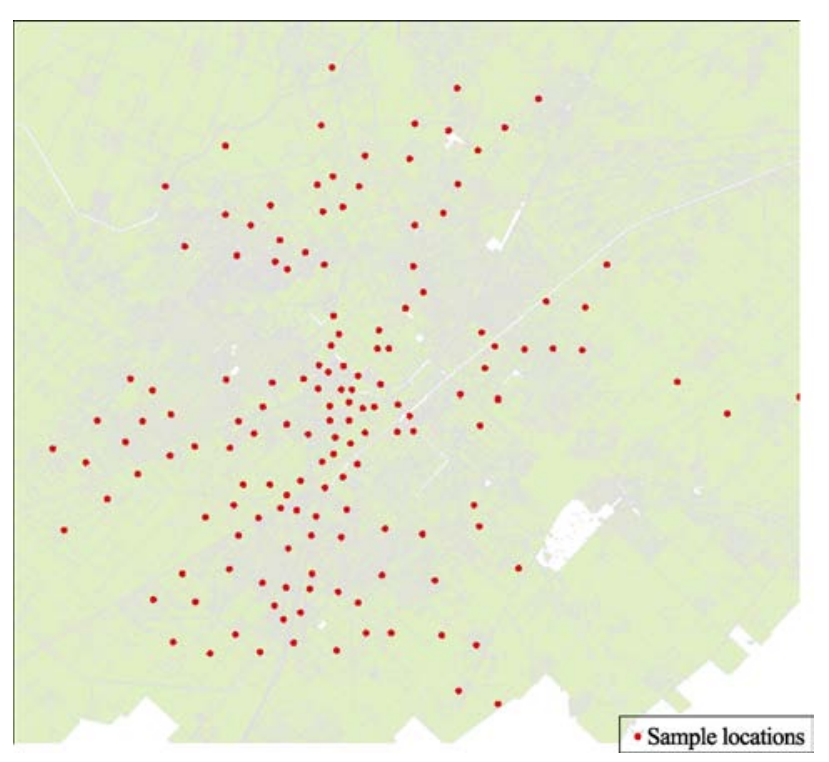

Figure 1 Groundwater sampling locations shown on the street map of Faisalabad city managing, creating, and analyzing geographic data. The sampling sites were marked in ArcMap with the help of their coordinates and maps of heavy metals in groundwater were produced. The Inverse Distance Weighted (IDW) interpolation technique was used for this purpose. IDW uses the measured values surrounding the prediction location to predict a value for any non-sampled location, based on the assumption that things that are close to one another are more alike than those that are farther apart.

\subsection{Statistical tools}

Multivariate data analysis was carried out using statistical package Minitab (version 13.2) for analysis of variance (ANOVA), Pearson's correlation and comparison of means.

\section{Results and discussion}

The present study was undertaken to determine the suitability of groundwater for drinking purpose with respect to heavy metal concentrations. The precise estimation of heavy metals in the water samples was made through chemical analysis and statistical approach. Analysis of variance (ANOVA) test showed that there was no statistically significant difference $(p>0.05)$ for $\mathrm{Zn}$, Cd and Ni concentration of groundwater among different localities of Faisalabad city. However, $\mathrm{Pb}$ and Fe levels of groundwater sampled revealed a highly significant difference $(p<0.01)$ showing that concentration of these elements varied significantly from place to place. Another significant difference $(p<0.05)$ was evaluated for $\mathrm{Cu}$ and $\mathrm{Mn}$ concentration in groundwater of Faisalabad city. The study of comparison of means showed that mean $\mathrm{Zn}$ content from the studied localities was $0.224 \pm 0.37 \mathrm{ppm}$. While, mean level (ppm) for $\mathrm{Cu}, \mathrm{Cd}, \mathrm{Ni}, \mathrm{Pb}, \mathrm{Mn}$ and Fe was $0.038 \pm 0.02,0.02 \pm 0.01,0.046 \pm 0.02,0.024 \pm 0.01$, $0.012 \pm 0.01$ and $0.024 \pm 0.01$, respectively (Table 1 ). 
Table 1 Comparison of means \pm SD (standard deviation) of concentrations (ppm) for studied heavy metals at all sampling sites

\begin{tabular}{|c|c|c|c|c|c|c|c|c|}
\hline $\begin{array}{l}\text { Sr. } \\
\text { No. }\end{array}$ & locations & $\pm \mathrm{SD}$ & D & $d \pm$ & $\mathrm{i} \pm \mathrm{SD}$ & $b \pm S D$ & D & D \\
\hline 1 & thanwala & $39 \pm 0.3$ & $33 \pm 0.0$ & $17 \pm 0.01$ & 2 & .02 & $0.011 \pm 0.01$ & $.016 \pm 0.01$ \\
\hline 2 & shid Abad & $322 \pm 0.31$ & $0.03 \pm 0.01$ & $0.011 \pm 0.01$ & $0.051 \pm 0.02$ & $0.029 \pm 0.02$ & $0.017 \pm 0.02$ & $0.031 \pm 0.02$ \\
\hline 3 & Saif Abad & $.271 \pm 0.2^{\prime}$ & $0.028 \pm 0.0$ & $0.021 \pm 0.01$ & $0.039 \pm 0.02$ & $0.029 \pm 0.02$ & $0.011 \pm 0.01$ & $0.019 \pm 0.01$ \\
\hline 4 & Shadab Colony & $0.454 \pm 0.5$ & $0.048 \pm 0.0$ & $0.028 \pm 0.01$ & $0.045 \pm 0.02$ & $0.009 \pm 0.01$ & $0.009 \pm 0.01$ & $0.012 \pm 0.01$ \\
\hline 5 & $\begin{array}{l}\text { Ali Housing } \\
\text { Colony }\end{array}$ & $099 \pm 0.01$ & $0.028 \pm 0.0$ & $0.013 \pm 0.02$ & $0.047 \pm 0.02$ & $0.012 \pm 0.01$ & $0.02 \pm 0.01$ & $0.012 \pm 0.01$ \\
\hline 6 & tan & $401 \pm 0.4$ & $0.032 \pm 0.0$ & $0.01 \pm 0.01$ & $0.054 \pm 0.01$ & $0.021 \pm 0.01$ & $0.011 \pm 0.01$ & $0.011 \pm 0.01$ \\
\hline 7 & Sheikh Colony & $0.078 \pm 0.0$ ? & $0.025 \pm 0.0$ & $0.017 \pm 0.02$ & $0.057 \pm 0.01$ & $0.036 \pm 0.01$ & $0.018 \pm 0.01$ & $0.019 \pm 0.01$ \\
\hline 8 & Liaquat Abad & $0.546 \pm 0.4 !$ & $0.026 \pm 0.0$ & $0.007 \pm 0.01$ & $0.05 \pm 0.02$ & $0.026 \pm 0.01$ & $0.005 \pm 0.01$ & $0.007 \pm 0.01$ \\
\hline 9 & Liaquat Town & $0.422 \pm 0.6 !$ & $0.034 \pm 0.0$ ? & $0.005 \pm 0.01$ & $0.033 \pm 0.03$ & $0.017 \pm 0.01$ & $0.012 \pm 0.01$ & $0.015 \pm 0.01$ \\
\hline 10 & Afghan Abad & $0.436 \pm 0.31$ & $0.032 \pm 0.0$ & $0.021 \pm 0.01$ & $0.051 \pm 0.01$ & $0.01 \pm 0.01$ & $0.016 \pm 0.01$ & $0.024 \pm 0.01$ \\
\hline 11 & $\begin{array}{l}\text { Guru Nanak } \\
\text { Pura }\end{array}$ & $0.139 \pm 0.1 !$ & $0.035 \pm 0.0$ & $0.016 \pm 0.02$ & $0.057 \pm 0.01$ & $0.024 \pm 0.01$ & $0.006 \pm 0.01$ & $0.019 \pm 0.01$ \\
\hline 12 & Gulberg & $0.136 \pm 0.11$ & $0.024 \pm 0.0$ & $0.003 \pm 0.01$ & $0.038 \pm 0.01$ & $0.007 \pm 0.01$ & $0.006 \pm 0.01$ & $0.014 \pm 0.01$ \\
\hline 13 & Jinnah Colony & $0.438 \pm 0.6 !$ & $0.048 \pm 0.0$ : & $0.038 \pm 0.01$ & $0.030 \pm 0.02$ & $0.013 \pm 0.01$ & $0.014 \pm 0.01$ & $0.031 \pm 0.01$ \\
\hline 14 & GC University & $0.19 \pm 0.08$ & $0.022 \pm 0.0$ & $0.019 \pm 0.01$ & $0.036 \pm 0.01$ & $0.021 \pm 0.01$ & $0.015 \pm 0.01$ & $0.026 \pm 0.01$ \\
\hline 15 & UAF & $0.326 \pm 0.3 !$ & $0.034 \pm 0.0$ & $0.019 \pm 0.01$ & $0.036 \pm 0.02$ & $0.025 \pm 0.01$ & $0.011 \pm 0.01$ & $0.019 \pm 0.01$ \\
\hline 16 & Raza Abad & $0.333 \pm 0.41$ & $0.052 \pm 0.0$ & $0.018 \pm 0.02$ & $0.053 \pm 0.01$ & $0.016 \pm 0.01$ & $0.008 \pm 0.01$ & $0.018 \pm 0.01$ \\
\hline 17 & G.M. Abad & $0.265 \pm 0.11$ & $0.035 \pm 0.0$; & $0.017 \pm 0.01$ & $0.061 \pm 0.01$ & $0.021 \pm 0.01$ & $0.014 \pm 0.01$ & $0.019 \pm 0.01$ \\
\hline 18 & IarziPura & $0.098 \pm 0.1$ & $0.05 \pm 0.02$ & $0.019 \pm 0.01$ & $0.04 \pm 0.02$ & $0.022 \pm 0.01$ & $0.014 \pm 0.01$ & $0.016 \pm 0.01$ \\
\hline 19 & IBGE & $0.215 \pm 0.2 !$ & $0.033 \pm 0.0$ & $0.015 \pm 0.01$ & $0.05 \pm 0.01$ & $0.008 \pm 0.01$ & $0.016 \pm 0.01$ & $0.045 \pm 0.01$ \\
\hline 20 & IAB & $.089 \pm 0.0$ & $0.043 \pm 0.0$ & $0.021 \pm 0.01$ & $0.049 \pm 0.01$ & $0.006 \pm 0.01$ & $0.015 \pm 0.01$ & $0.022 \pm 0.01$ \\
\hline 21 & ARI & $.078 \pm 0.0$ & $0.04 \pm 0.02$ & $0.021 \pm 0.02$ & $0.045 \pm 0.02$ & $.02 \pm 0.01$ & $0.008 \pm 0.01$ & $0.016 \pm 0.01$ \\
\hline 22 & rub Cc & $.041 \pm 0.0$. & $0.039 \pm 0.0$; & $0.022 \pm 0.02$ & $0.03 \pm 0.01$ & $0.033 \pm 0.02$ & $0.014 \pm 0.01$ & $0.022 \pm 0.01$ \\
\hline 23 & Pertap Nagar & $.02 \pm 0.01$ & $0.057 \pm 0.0$ : & $0.032 \pm 0.01$ & $0.056 \pm 0.01$ & $0.022 \pm 0.01$ & $0.011 \pm 0.01$ & $0.019 \pm 0.01$ \\
\hline 24 & zim Abad & $.125 \pm 0.1 !$ & $0.031 \pm 0.0$ & $0.025 \pm 0.02$ & $0.04 \pm 0.01$ & $0.013 \pm 0.01$ & $0.007 \pm 0.01$ & $0.028 \pm 0.01$ \\
\hline 25 & alid Abad & $.172 \pm 0.0$ & $0.04 \pm 0.03$ & $0.028 \pm 0.02$ & $0.072 \pm 0.01$ & $0.03 \pm 0.02$ & $0.008 \pm 0.01$ & $0.018 \pm 0.01$ \\
\hline 26 & rchernPura & $.321 \pm 0.4 !$ & $0.054 \pm 0.0$ & $0.023 \pm 0.01$ & $0.037 \pm 0.02$ & $0.012 \pm 0.01$ & $0.002 \pm 0.01$ & $0.02 \pm 0.01$ \\
\hline 27 & natPura & $219 \pm 0.2$ & $0.028 \pm 0.0$ & $0.018 \pm 0.02$ & $0.044 \pm 0.01$ & $0.03 \pm 0.01$ & $0.016 \pm 0.01$ & $0.03 \pm 0.01$ \\
\hline 28 & DiglosPura & $.092 \pm 0.0$ & $0.034 \pm 0.0$ : & $0.02 \pm 0.01$ & $0.056 \pm 0.01$ & $0.036 \pm 0.02$ & $0.009 \pm 0.01$ & $0.024 \pm 0.02$ \\
\hline 29 & ock Tower & $.066 \pm 0.0$ & $0.029 \pm 0.0$ & $0.024 \pm 0.01$ & $0.051 \pm 0.01$ & $0.026 \pm 0.01$ & $0.023 \pm 0.01$ & $0.026 \pm 0.02$ \\
\hline 30 & Jhang Road & $.045 \pm 0.0$ & $0.023 \pm 0.0$; & $0.034 \pm 0.01$ & $0.049 \pm 0.01$ & $.02 \pm 0.02$ & $0.005 \pm 0.01$ & $0.019 \pm 0.01$ \\
\hline 31 & & $12 \pm 0.08$ & $0.069 \pm 0.0$; & $0.035 \pm 0.02$ & $0.034 \pm 0.01$ & $0.021 \pm 0.01$ & $0.022 \pm 0.01$ & $0.017 \pm 0.01$ \\
\hline 32 & DHQ & $.494 \pm 0.6$ & $0.068 \pm 0.0$ & $0.017 \pm 0.01$ & $0.043 \pm 0.01$ & $0.025 \pm 0.02$ & $0.009 \pm 0.01$ & $0.022 \pm 0.01$ \\
\hline 33 & $\begin{array}{l}\text { Allied Hospi- } \\
\text { tal/PINUM }\end{array}$ & $0.673 \pm 0.4 \imath$ & $0.036 \pm 0.0$ & $0.012 \pm 0.01$ & $0.062 \pm 0.01$ & $0.032 \pm 0.02$ & $0.022 \pm 0.01$ & $0.033 \pm 0.01$ \\
\hline 34 & Sargodha Road & $252 \pm 0.2$ & $0.037 \pm 0.0$ & $0.021 \pm 0.01$ & $0.045 \pm 0.01$ & $0.038 \pm 0.02$ & $0.008 \pm 0.01$ & $0.034 \pm 0.01$ \\
\hline 35 & Gulistan Colon】 & $0.124 \pm 0.1$ « & $0.054 \pm 0.0$ & $0.032 \pm 0.01$ & $0.063 \pm 0.01$ & $0.049 \pm 0.01$ & $0.009 \pm 0.01$ & $0.025 \pm 0.02$ \\
\hline 36 & Abdullah Pur & $0.066 \pm 0.0 ?$ & $0.03 \pm 0.01$ & $0.023 \pm 0.01$ & $0.047 \pm 0.01$ & $0.025 \pm 0.01$ & $0.007 \pm 0.01$ & $0.025 \pm 0.01$ \\
\hline 37 & Canal Road & $0.054 \pm 0.0$ & $0.049 \pm 0.0$ & $0.016 \pm 0.01$ & $0.029 \pm 0.02$ & $0.013 \pm 0.01$ & $0.007 \pm 0.01$ & $0.034 \pm 0.02$ \\
\hline
\end{tabular}


(Continued)

\begin{tabular}{|c|c|c|c|c|c|c|c|c|}
\hline $\begin{array}{l}\text { Sr. } \\
\text { No. }\end{array}$ & $\begin{array}{l}\text { Sampling } \\
\text { locations }\end{array}$ & $\mathrm{Zn} \pm \mathrm{SD}$ & $\mathrm{Cu} \pm \mathrm{SD}$ & $\mathrm{Cd} \pm \mathrm{SD}$ & $\mathrm{Ni} \pm \mathrm{SD}$ & $\mathrm{Pb} \pm \mathrm{SD}$ & $\mathrm{Mn} \pm \mathrm{SD}$ & $\mathrm{Fe} \pm \mathrm{SD}$ \\
\hline 38 & Madina Town & $0.511 \pm 0.31$ & $0.038 \pm 0.0$ & $0.017 \pm 0.01$ & $0.035 \pm 0.0$ & $0.022 \pm 0.0$ & $0.007 \pm 0.0$ & $0.034 \pm 0.0$ ' \\
\hline 39 & Officers Colony & $0.117 \pm 0.01$ & $0.058 \pm 0.0$ & $0.028 \pm 0.01$ & $0.065 \pm 0.0$ & $0.023 \pm 0.0$ & $0.003 \pm 0.0$ & $0.032 \pm 0.0$ \\
\hline 40 & Satiana Road & $0.196 \pm 0.1^{\prime}$ & $0.039 \pm 0.0$ & $0.026 \pm 0.01$ & $0.037 \pm 0.0:$ & $0.047 \pm 0.0$ & $0.015 \pm 0.0$ & $0.043 \pm 0.0^{\prime}$ \\
\hline 41 & Batala Colony & $0.05 \pm 0.03$ & $0.041 \pm 0.0$ & $0.013 \pm 0.01$ & $0.038 \pm 0.0:$ & $0.026 \pm 0.0$ & $0.019 \pm 0.0$ & $0.02 \pm 0.01$ \\
\hline 42 & Peoples Colony & $0.206 \pm 0.1$ & $0.032 \pm 0.0$ & $0.021 \pm 0.02$ & $0.046 \pm 0.0:$ & $0.016 \pm 0.0$ & $0.015 \pm 0.0$ & $0.034 \pm 0.0$ \\
\hline 43 & D Ground & $0.054 \pm 0.0$ & $0.055 \pm 0.0$ & $0.03 \pm 0.01$ & $0.042 \pm 0.0$ & $0.009 \pm 0.0$ & $0.017 \pm 0.0$ & $0.033 \pm 0.0$ \\
\hline 44 & WarisPura & $0.103 \pm 0.0$ & $0.02 \pm 0.01$ & $0.032 \pm 0.01$ & $0.056 \pm 0.0$ & $0.033 \pm 0.0$ & $0.01 \pm 0.01$ & $0.033 \pm 0.0$ \\
\hline 45 & Jaranwala Road & $1.14 \pm 1.84$ & $0.03 \pm 0.01$ & $0.033 \pm 0.01$ & $0.055 \pm 0.0$ & $0.032 \pm 0.0$ ' & $0.013 \pm 0.0$ & $0.017 \pm 0.0$ \\
\hline 46 & Dhuddiwala & $0.328 \pm 0.2$ & $0.031 \pm 0.0$ & $0.009 \pm 0.01$ & $0.043 \pm 0.0$ & $0.056 \pm 0.0$ & $0.023 \pm 0.0$ & $0.032 \pm 0.0$ \\
\hline 47 & Samundari Road & $0.083 \pm 0.0$ & $0.048 \pm 0.0$ & $0.024 \pm 0.01$ & $0.041 \pm 0.0$ & $0.007 \pm 0.0$ & $0.008 \pm 0.0$ & $0.015 \pm 0.0$ \\
\hline 48 & Amin Abad & $0.027 \pm 0.0$ & $0.036 \pm 0.0$ & $0.014 \pm 0.01$ & $0.054 \pm 0.0$ & $0.015 \pm 0.0$ & $0.009 \pm 0.0$ & $0.018 \pm 0.0$ \\
\hline 49 & Mehmood Abad & $0.034 \pm 0.0$ & $0.029 \pm 0.0$ & $0.029 \pm 0.01$ & $0.048 \pm 0.0:$ & $0.016 \pm 0.0$ & $0.006 \pm 0.0$ & $0.03 \pm 0.02$ \\
\hline 50 & Nisar Colony & $0.054 \pm 0.0$ & $0.039 \pm 0.0$ & $0.016 \pm 0.01$ & $0.033 \pm 0.0:$ & $0.055 \pm 0.0$ & $0.005 \pm 0.0$ & $0.037 \pm 0.0$ \\
\hline 51 & Jawala Nagar & $0.042 \pm 0.0$ & $0.039 \pm 0.0$ & $0.017 \pm 0.01$ & $0.039 \pm 0.0:$ & $0.027 \pm 0.0$ & $0.007 \pm 0.0$ & $0.025 \pm 0.0$ \\
\hline \multirow[t]{2}{*}{52} & Nawabanwala & $0.248 \pm 0.31$ & $0.038 \pm 0.0$ & $0.019 \pm 0.01$ & $0.04 \pm 0.02$ & $0.032 \pm 0.0$ & $0.01 \pm 0.01$ & $0.031 \pm 0.0$ \\
\hline & Grand total & $0.224 \pm 0.3^{\prime}$ & $0.038 \pm 0.0:$ & $0.02 \pm 0.01$ & $0.046 \pm 0.0:$ & $0.024 \pm 0.0$ & $0.012 \pm 0.0$ & $0.024 \pm 0.0$ \\
\hline
\end{tabular}

\subsection{Correlation among heavy metal concentrations}

The interrelationship or association among all the heavy metals studied was evaluated by Pearson correlation analysis (Table 2).

Table 2 Relationship among different heavy metals for all sampling sites (Pearson Correlation among different heavy metals)

\begin{tabular}{cccccccc}
\hline & $\mathrm{Zn}$ & $\mathrm{Cu}$ & $\mathrm{Cd}$ & $\mathrm{Ni}$ & $\mathrm{Pb}$ & $\mathrm{Mn}$ & $\mathrm{Fe}$ \\
\hline \multirow{2}{*}{$\mathrm{Cu}$} & $0.038^{\mathrm{NS}}$ & 1.00 & & & & & \\
& $\mathrm{P}=0.634$ & & & & & & \\
$\mathrm{Cd}$ & $-0.066^{\mathrm{NS}}$ & $0.160^{*}$ & 1.00 & & & & \\
& $\mathrm{P}=0.414$ & $\mathrm{P}=0.045$ & & & & & \\
& $0.025^{\mathrm{NS}}$ & $-0.014^{\mathrm{NS}}$ & $-0.024^{\mathrm{NS}}$ & & & & \\
$\mathrm{Ni}$ & $\mathrm{P}=0.757$ & $\mathrm{P}=0.865$ & $\mathrm{P}=0.770$ & 1.00 & & & \\
& $0.056^{\mathrm{NS}}$ & $-0.091^{\mathrm{NS}}$ & $-0.031^{\mathrm{NS}}$ & $0.044^{\mathrm{NS}}$ & 1.00 & & \\
$\mathrm{~Pb}$ & $\mathrm{P}=0.487$ & $\mathrm{P}=0.257$ & $\mathrm{P}=0.702$ & $\mathrm{P}=0.582$ & & & \\
& $0.207^{* *}$ & $-0.110^{\mathrm{NS}}$ & $0.010^{\mathrm{NS}}$ & $-0.071^{\mathrm{NS}}$ & $0.072^{\mathrm{NS}}$ & 1.00 & \\
$\mathrm{Mn}$ & $\mathrm{P}=0.010$ & $\mathrm{P}=0.173$ & $\mathrm{P}=0.903$ & $\mathrm{P}=0.382$ & $\mathrm{P}=0.373$ & & \\
& $-0.033^{\mathrm{NS}}$ & $-0.052^{\mathrm{NS}}$ & $0.112^{\mathrm{NS}}$ & $-0.088^{\mathrm{NS}}$ & $0.139^{\mathrm{NS}}$ & $0.208^{* *}$ & \\
$\mathrm{Fe}$ & $\mathrm{P}=0.678$ & $\mathrm{P}=0.516$ & $\mathrm{P}=0.162$ & $\mathrm{P}=0.272$ & $\mathrm{P}=0.083$ & $\mathrm{P}=0.009$ & \\
Depth & $-0.072^{\mathrm{NS}}$ & $0.084^{\mathrm{NS}}$ & $0.163^{*}$ & $0.038^{\mathrm{NS}}$ & $-0.010^{\mathrm{NS}}$ & $-0.037^{\mathrm{NS}}$ & $0.093^{\mathrm{NS}}$ \\
$\mathrm{ft})$ & $\mathrm{P}=0.371$ & $\mathrm{p}=0.297$ & $\mathrm{p}=0.043$ & $\mathrm{p}=0.641$ & $\mathrm{p}=0.906$ & $\mathrm{p}=0.643$ & $\mathrm{p}=0.251$ \\
\hline
\end{tabular}

$*=$ Significant $(\mathrm{P}<0.05) ; * *=$ Highly significant $(\mathrm{P}<0.01)$; NS=Non-significant $(\mathrm{P}>0.05)$

The relationship among all the heavy metals ( $\mathrm{Zn}, \mathrm{Cu}, \mathrm{Cd}, \mathrm{Ni}, \mathrm{Pb}, \mathrm{Mn}$ and $\mathrm{Fe}$ ) studied was found non-significant $(p>0.05)$ revealing that there is no correlation between them with a few exceptions [Mn-Zn $(p=0.010)$, Mn-Fe $(p=0.009)$ and Cu-Cd $(p=0.045)]$. In other words, the concentration of these metals does not depend upon each other. A highly significant $(p<0.01)$ and positive correlation of Mn was observed with $\mathrm{Zn}(r=0.207)$, this result is 
in agreement with earlier observations of Farooq et al. (2010). They estimated levels of selected heavy metals such as $\mathrm{Cd}, \mathrm{Cr}, \mathrm{Cu}, \mathrm{Fe}, \mathrm{Ni}, \mathrm{Zn}, \mathrm{Mn}, \mathrm{Hg}$ and $\mathrm{Pb}$ in water samples used for irrigation from the catchment area of Malir River, a sub-urban eastern area of Karachi. In this study Mn showed a positive correlation with Zn pointing out that Mn concentration of groundwater increases with an increase in $\mathrm{Zn}$ level and vice versa. Similarly, another highly significant $(p<0.01)$ and positive correlation of Mn was observed with Fe $(r=0.208)$, indicating that Mn level of groundwater increases with an increase in Fe level and vice versa. The present study also contradicted the findings of Farooq et al. (2010), where Fe showed a negative correlation with all detected metal ions such as $\mathrm{Cd}, \mathrm{Cr}, \mathrm{Cu}, \mathrm{Fe}, \mathrm{Ni}, \mathrm{Zn}, \mathrm{Mn}, \mathrm{Hg}$ and $\mathrm{Pb}$ in water samples used for irrigation from the catchment area of Malir River, sub-urban eastern area of Karachi. In the present study significant and positive correlation was found between $\mathrm{Cu}$ and $\mathrm{Cd}$. The study conducted by Mastoi et al. (2008) also revealed that the concentration of $\mathrm{Cu}$ was significantly and positively correlated with the concentration of $\mathrm{Ni}$ $(r=0.804, p<0.01)$, Co $(r=0.974, p<0.05)$ and Cd $(r=0.903, p<0.05)$. Another finding of the study by Mastoi et al. (2008) was significant and positive correlation between the concentrations of $\mathrm{Ni}(r=0.991, p<0.01)$ and $\mathrm{Zn}(r=0.921, p<0.05)$ which is not substantiated by the present study, as non-significant relationship was observed ( $p>0.05)$ between $\mathrm{Ni}$ and $\mathrm{Zn}$. Another significant $(p<0.05)$ and positive relationship was found between $\mathrm{Cu}$ and $\mathrm{Cd}$ showing that there is strong association between $\mathrm{Cu}$ and $\mathrm{Cd}$ concentration of groundwater in the study area. Pearson's correlation revealed that there was non-significant $(p>0.05)$ and positive relationship between these metal pairs, i.e., $\mathrm{Zn}-\mathrm{Cu}(p=0.634), \mathrm{Zn}-\mathrm{Ni}(p=0.757)$, $\mathrm{Zn}-\mathrm{Pb}(p=0.487)$, Cd-Mn ( $p=0.903)$, Cd-Fe ( $p=0.162)$, Ni-Pb $(p=0.582), \mathrm{Pb}-\mathrm{Mn}(p=$ $0.373)$ and $\mathrm{Pb}-\mathrm{Fe}(p=0.083)$. From this correlation analysis it was found that the increase in the concentration of one metal will increase the concentration of the other respective metal pair. Another non-significant ( $p>0.05)$ and negative relationship was found between these metal pairs, i.e., $\mathrm{Zn}-\mathrm{Cd}(p=0.414), \mathrm{Zn}-\mathrm{Fe}(p=0.678)$, $\mathrm{Cu}-\mathrm{Ni}(p=0.865), \mathrm{Cu}-\mathrm{Pb}(p=0.257)$, Cu-Mn ( $p=0.173)$, Cu-Fe $(p=0.516)$, Cd-Ni $(p=0.770), \mathrm{Cd}-\mathrm{Pb}(p=0.702), \mathrm{Ni}-\mathrm{Mn}(p=$ $0.382)$ and Ni-Fe $(p=0.272)$. From this correlation analysis it was found that that increase in the concentration of one metal will decrease the concentration of the other respective metal pair. The study conducted by Akoto and Adiyiah (2007) also found no correlations between metal concentrations in the drinking water samples. They determined the trace metals and some physiochemical properties in drinking water samples from the Brong Ahafo region of the Republic of Ghana.

Another study conducted by Lodhi et al. (2003) concluded that there was no co-linearity among the metals. They analyzed drinking water quality in Skardu and other northern areas of Pakistan for various parameters like $\mathrm{pH}$, DO, EC, suspended solids, hardness, alkalinity, $\mathrm{NO}_{2}, \mathrm{Na}, \mathrm{SO}_{4}, \mathrm{Cl}$ and $\mathrm{K}$ and for heavy metals like $\mathrm{Fe}, \mathrm{Cr}, \mathrm{Zn}, \mathrm{Mn}, \mathrm{Cu}, \mathrm{Ni}, \mathrm{Co}$ and $\mathrm{Pb}$.

The study conducted by Majidano and Khuwahar (2009) found significant and positive relationship between $\mathrm{Fe}$ and $\mathrm{Zn}, \mathrm{Mn}$ and $\mathrm{Cd}, \mathrm{Cu}$ and $\mathrm{Zn}, \mathrm{Ni}$ and $\mathrm{Cd}$. This relationship is not substantiated by the present study as no such significant relationship was evaluated. The study conducted by Santos et al. (2000) revealed the strongest associations corresponded to the coexistence of $\mathrm{Zn}-\mathrm{Cd}$ and $\mathrm{Pb}-\mathrm{Cu}$ opposite to the finding of the present study, where non-significant $(p>0.05)$ and negative correlation was found between $\mathrm{Zn}$ and Cd (with $r=$ $-0.066)$. Similarly no correlation was observed between $\mathrm{Pb}$ and $\mathrm{Cu}(p=0.091)$. 
In the present study no significant correlation was observed between $\mathrm{Pb}$ and $\mathrm{Ni}$ concentration of groundwater. This result is in agreement with the findings of Akoto and Adiyiah (2007); Lodhi et al. (2003) while contradicted by the findings of Tariq et al. (2008). Tariq et al. (2008) estimated levels of selected metals $\mathrm{Na}, \mathrm{Ca}, \mathrm{Mg}, \mathrm{K}, \mathrm{Fe}, \mathrm{Mn}, \mathrm{Cr}, \mathrm{Co}, \mathrm{Ni}, \mathrm{Cd}, \mathrm{Pb}$ and $\mathrm{Mn}$ in groundwater samples from Kasur, a significant industrial city of Pakistan and found significantly positive correlation between $\mathrm{Pb}$ and $\mathrm{Ni}$.

Relationship of concentration of studied heavy metals with groundwater depth was evaluated showing significant $(p<0.05)$ and positive correlation between cadmium concentration and groundwater depth, while correlation for all other metals with depth was found non-significant $(p>0.05)$.

Correlation analysis showed that there was negative relationship of zinc, lead and manganese level with depth of groundwater, while concentrations of copper, nickel and iron showed positive correlation with groundwater depth. The statistical distribution of the studied heavy metal concentrations was compared with WHO standards (Table 3).

Table 3 Distribution of heavy metals in groundwater of Faisalabad

\begin{tabular}{cccccc}
\hline \multirow{2}{*}{ Heavy metals } & \multicolumn{5}{c}{ Concentrations of heavy metals (ppm) } \\
\cline { 2 - 5 } & Min & Max & Mean & SD & WHO Value \\
\hline Zn & 0.008 & 3.265 & 0.224 & \pm 0.374 & 3.000 \\
$\mathrm{Cu}$ & 0.011 & 0.088 & 0.038 & \pm 0.015 & 2.000 \\
$\mathrm{Cd}$ & 0.002 & 0.050 & 0.020 & \pm 0.012 & 0.003 \\
$\mathrm{Ni}$ & 0.007 & 0.085 & 0.046 & \pm 0.017 & 0.020 \\
$\mathrm{~Pb}$ & 0.002 & 0.065 & 0.024 & \pm 0.014 & 0.010 \\
$\mathrm{Mn}$ & 0.001 & 0.033 & 0.012 & \pm 0.007 & 0.500 \\
$\mathrm{Fe}$ & 0.004 & 0.061 & 0.024 & \pm 0.010 & 0.300
\end{tabular}

$\mathrm{SD}=$ standard deviation

\subsection{Comparison of heavy metal concentrations with WHO standards}

In the present study, contents of Zn (0.008-3.265), Cd (0.002-0.050), Ni (0.007-0.085) and $\mathrm{Pb}(0.002-0.065)$ levels were found above the recommended level of drinking water for human health set by WHO. The guideline values for drinking water set by WHO for Zn, Cd, $\mathrm{Ni}$ and $\mathrm{Pb}$ are $3.0 \mathrm{ppm}, 0.003 \mathrm{ppm}, 0.02 \mathrm{ppm}$ and $0.01 \mathrm{ppm}$, respectively. In the study conducted by PCRWR (2006) also found cadmium concentration above WHO standard in 15\% of water collected from 13 locations covering the major water sources of Faisalabad city.

Concentrations of $\mathrm{Cu}(0.011-0.088 \mathrm{ppm}), \mathrm{Mn}(0.001-0.033 \mathrm{ppm})$ and Fe (0.004-0.061 $\mathrm{ppm}$ ) were found under the safe limits set by WHO. The standard values set by WHO for $\mathrm{Cu}$, $\mathrm{Mn}$ and Fe are $2.0 \mathrm{ppm}, 0.5 \mathrm{ppm}$ and $0.3 \mathrm{ppm}$, respectively. Total number of samples and percentage values for all the heavy metals studied in the groundwater samples from different localities of Faisalabad city area that were found above and below WHO guideline values for drinking water are presented in Figures 2 and 3, respectively.

\subsection{Spatial distribution of heavy metals in groundwater}

Metal concentrations were mapped using GIS to identify and demark risk areas in terms of human exposure to heavy metal concentrations in groundwater from different urban areas of 


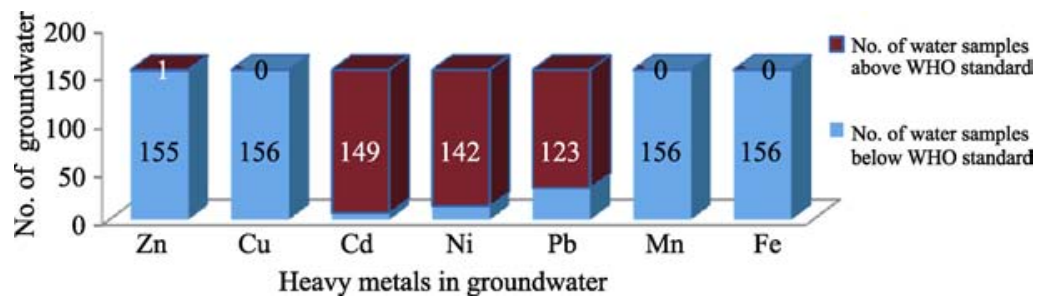

Figure 2 Number of groundwater samples above/below WHO standard

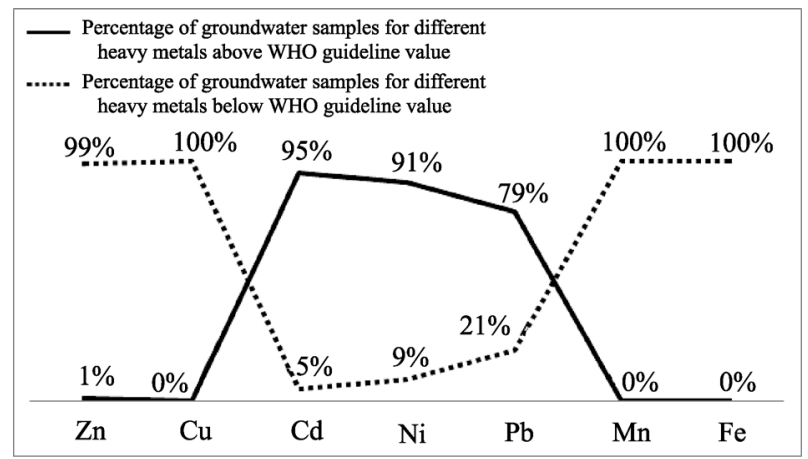

Figure 3 Percentage of groundwater samples above/below WHO guideline value

Faisalabad city. GIS mapping revealed that there is wide dispersion of values of all the heavy metals ( $\mathrm{Zn}, \mathrm{Cu}, \mathrm{Cd}, \mathrm{Ni}, \mathrm{Pb}, \mathrm{Mn}$ and $\mathrm{Fe}$ ) in groundwater of Faisalabad urban area.

The spatial distribution of $\mathrm{Zn}$ concentration is displayed in Figure 4 showing the highest concentration (3.265 ppm) in the sample collected from Jaranwala Road area that was beyond the WHO guideline value (3.0 ppm). The reason behind this high $\mathrm{Zn}$ concentration is, because the site is located near National Fertilizer Company (NFC), a fertilizer industry while in the majority of the samples the Zn concentrations varied from 0-1 ppm.

Great variation was found in the concentration of $\mathrm{Cu}$ in groundwater among different localities. All the samples were found within the safe limits (below $2.0 \mathrm{ppm}$ ) set by WHO as it is displayed by Figure 5. Figure 6 displays the spatial distribution of $\mathrm{Cd}$ concentration among different localities. Cd concentrations in majority of the samples were found above the WHO standard (0.003 ppm). While the samples collected from Gulberg, Sheikh Colony, GM Abad, Nisar Colony, Dhuddiwala and Peoples Colony were well within the safe limits. The lowest Cd concentration found was $0.002 \mathrm{ppm}$ in the groundwater samples.

The spatial distribution of Ni concentration is shown in Figure 7, where Ni content was found above WHO standard (0.02 ppm). The highest concentration $(0.085 \mathrm{ppm})$ was found in Khalidabad area where hosiery industry is housed and possibly releases Ni contaminated effluents.

Similarly $\mathrm{Pb}$ concentrations revealed great variation among different localities as it is displayed in Figure 8, where the highest level of $\mathrm{Pb}$ was found in Dhuddiwala area possibly due to seepage $\mathrm{Pb}$ rich effluent from the nearby sewage drain named "Dhudiwala Minor". The same was found at minimum concentration in the sample taken from the area of NIAB. Spatial variation of Mn (Figure 9) and Fe concentration (Figure 10) showed that all the groundwater samples were under the prescribed limit set by WHO. There was a great variation in groundwater depth among various sampling points in different localities of Faisalabad city 


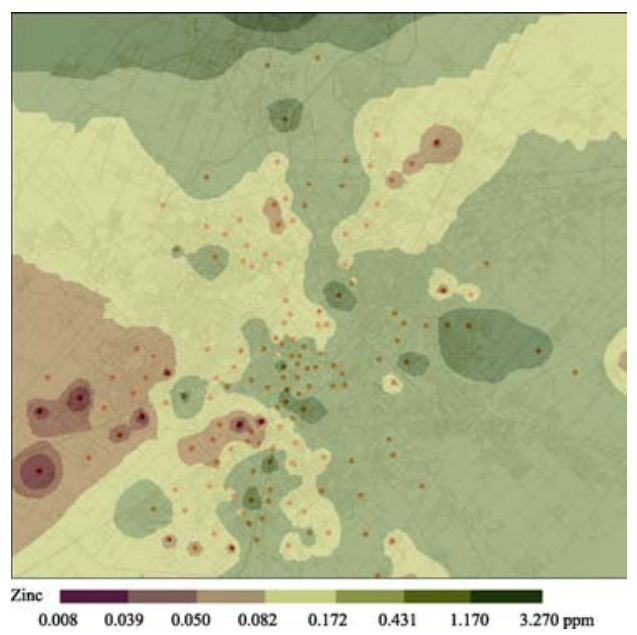

Figure 4 Zn level in groundwater of Faisalabad city in 2009

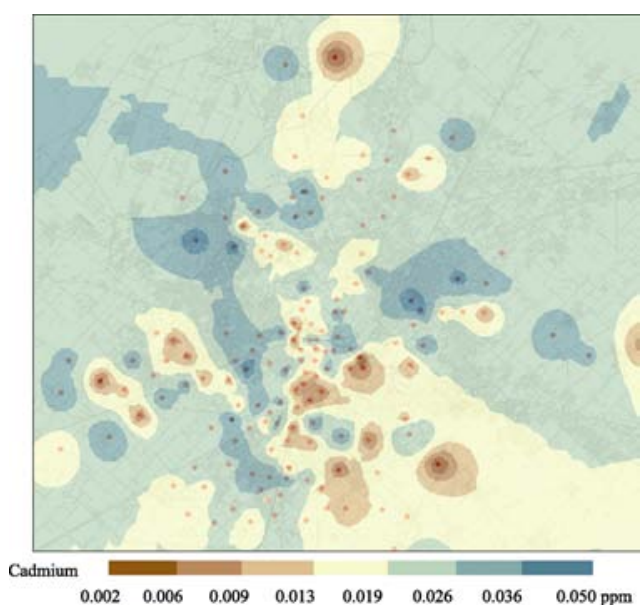

Figure $6 \mathrm{Cd}$ level in groundwater of Faisalabad city in 2009

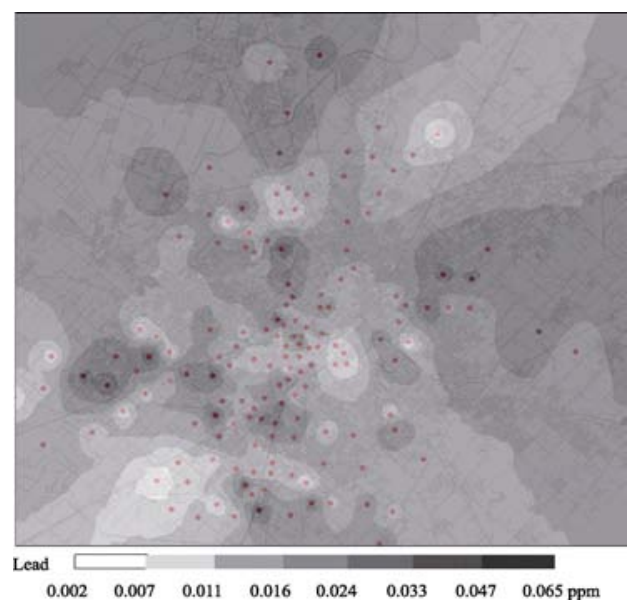

Figure $8 \mathrm{~Pb}$ level in groundwater of Faisalabad city in 2009

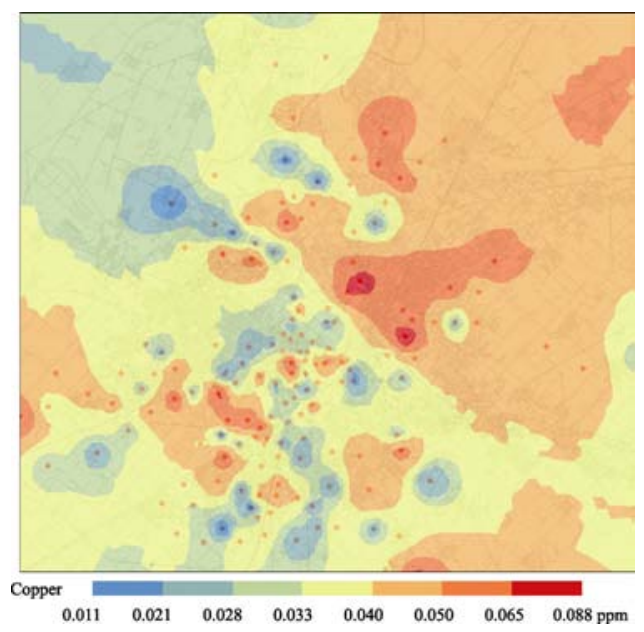

Figure $5 \mathrm{Cu}$ level in groundwater of Faisalabad city in 2009

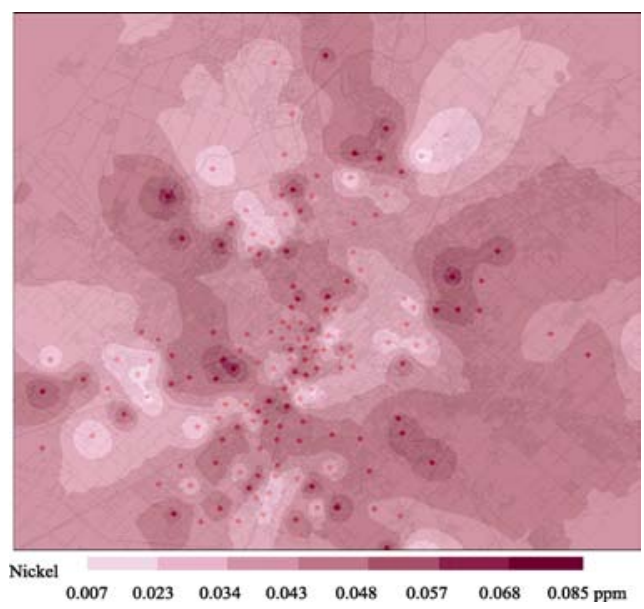

Figure 7 Ni level in groundwater of Faisalabad city in 2009

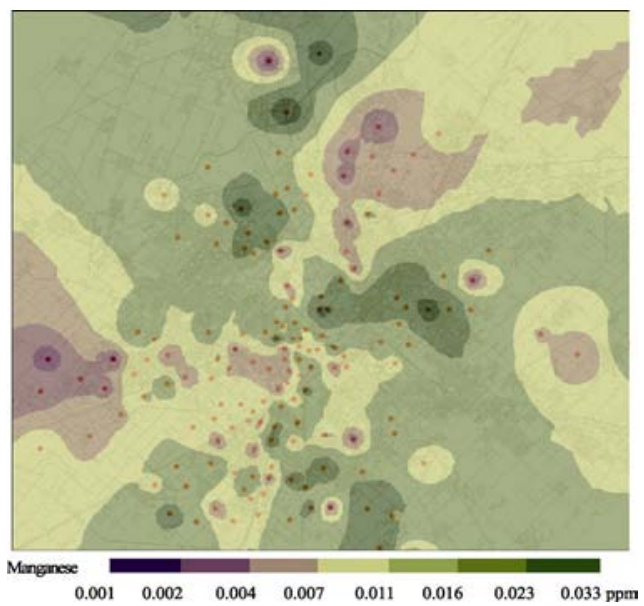

Figure 9 Mn level in groundwater of Faisalabad city in 2009 


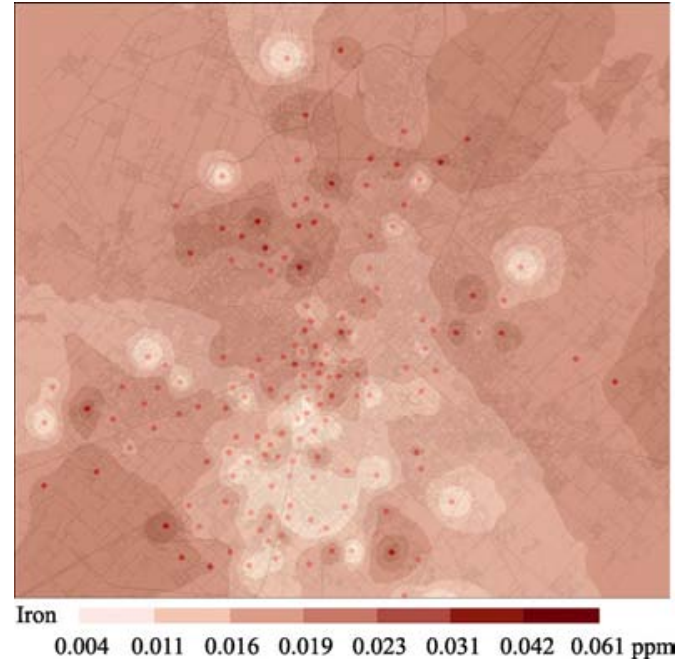

Figure 10 Fe level in groundwater of Faisalabad city in 2009

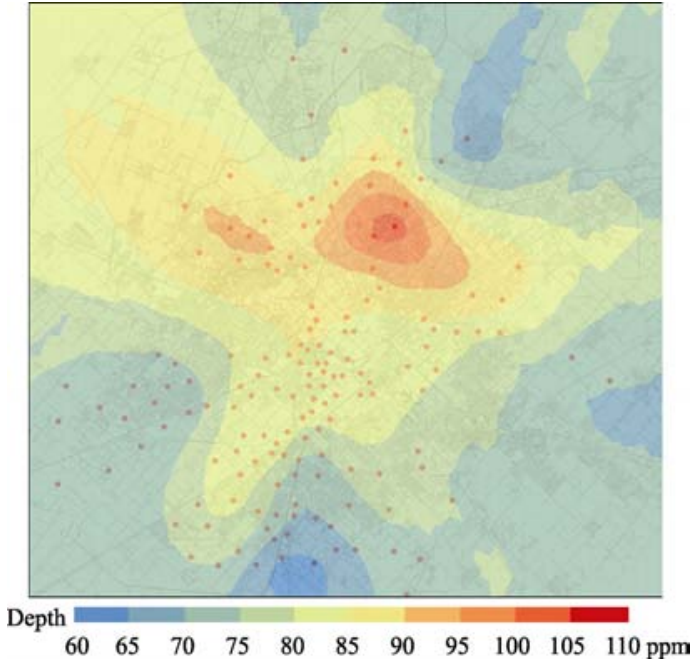

Figure 11 Depth of samples at different locations of Faisalabad city

(Figure 11). A possible reason is the difference in level of groundwater pumping in various areas that depends on the intended use of water (e.g., domestic or agricultural) and size of population.

\section{Conclusions}

The present study revealed that the levels of $\mathrm{Cu}, \mathrm{Mn}$ and $\mathrm{Fe}$ were found below the recommended guideline values for drinking water set by World Health Organization (WHO); i.e., 2.0, 0.50 and $0.30 \mathrm{ppm}$, respectively. While the concentrations of $\mathrm{Zn}, \mathrm{Cd}, \mathrm{Ni}$ and $\mathrm{Pb}$ in groundwater were found above the recommended level of drinking water set by WHO; i.e., 3.0, 0.003, 0.02 and $0.01 \mathrm{ppm}$, respectively for human health. No significant correlation ( $p>0.05$ ) was found among the occurrence of studied heavy metals with a few exceptions (Mn-Zn, Mn-Fe and Cu-Cd). A highly significant and positive correlation $(p<0.01)$ of Mn was found with $\mathrm{Zn}(p=0.010$ and $r=0.207)$ and Fe $(p=0.009$ and $r=0.208)$ indicating that $\mathrm{Zn}$ and $\mathrm{Fe}$ level of groundwater increases with an increase in $\mathrm{Mn}$ level and vice versa. Another significant and positive correlation $(\mathrm{p}<0.05)$ was found between $\mathrm{Cu}$ and $\mathrm{Cd}(p=$ 0.045 and $r=0.160$ ) showing that there is strong association between $\mathrm{Cu}$ and $\mathrm{Cd}$ concentrations of groundwater in the study area. Groundwater monitoring results were mapped using GIS to show the regional patterns of occurrence of heavy metal concentrations in groundwater of Faisalabad city.

\section{Acknowledgements}

The data presented here is part of Master's thesis of Sobia Ashraf at GC University Faisalabad. All authors contributed significantly during planning, execution and write up of this article. The authors are grateful to Ayub Agriculture Research Institute (AARI), Faisalabad for help in sampling and analysis. 


\section{References}

Ahmad I, Athar M, Sarwar F, 2004. Surface water suitability for drinking purpose in Cholistan Desert. J. Biol. Sci., 4(1): 34-39.

Ahmad K, Ibrahim M, Khan Z I et al., 2011. Effect of sewage water on mineral nutritive potential of six fodder species grown under semiarid conditions. Saudi J. Biol. Sci., 18: 317-321.

Ahmad K, Khan Z I, Ashraf M et al., 2008. Status of plant diversity at Kufri (Soone valley) Punjab, Pakistan and prevailing threats therein. Pak. J. Bot., 40: 993-997.

Ahmad K, Khan Z I, Ibrahim M et al., 2010. Evaluation of nutritional composition of plant species of Soone valley in Punjab, Pakistan. J. Plant Nutr., 33: 496-517.

Ahmad Z, Anwar Q, 2011. Source evaluation of physicochemically contaminated groundwater of Dera Ismail Khan area, Pakistan. Env. Monitor. Assess., 175(1-4): 9-21.

Akhter G, Zulfiqar A, Javed I et al., 2010. Physicochemical characterization of groundwater in urban areas of Lahore, Pakistan, with special reference to arsenic. J. Chem. Society Pak., 32(3): 306-312.

Akoto O, Adiyiah J, 2007. Chemical analysis of drinking water from some communities in the Brong Ahafo region. Int. J. Environ. Sci. Tech., 4 (2): 211-214.

Fardous A, Gondal S, Shah Z A et al., 2010. Sodium, potassium and magnesium dynamics in soil-plant-animal continuum. Pak. J. Bot., 42: 2411-2421.

Farooq M A, Yasmin N, Mughal S et al., 2010. Human Induced Impact on Malir River Basin Karachi, Pakistan. World Appl. Sci. J., 9(12): 1450-1456.

Ibrahim M, Han K H, Ha S K et al., 2012. Physico-chemical characteristics of disturbed soils affected by accumulate of different texture in South Korea. Sains. Malays., 41(3): 285-291.

Igwilo I O, Afonne O J, Maduabuchi U J et al., 2006. Toxicological study of the Anam River in Otuocha, Anambra State, Nigeria. Arch. Environ. Occup. Health, 61(5): 205-208.

Ilyas A, Sarwar T, 2003 Study of trace elements in drinking water in the vicinity of Palosi Drain, Peshawar. Pak. J. Biol. Sci., 6(1): 86-91.

Irfan M, Ibrahim M, Rashid U et al., 2013. Optimization of Cr (III) removal from wastewater using Thespesia populenea particles by response surface methodology. Asian J. Chem., 25(15): 224-255

Kausar R, Zulfiqar A, 2009. Determination of toxic inorganic elements pollution in ground waters of Kahuta industrial triangle Islamabad, Pakistan using inductively coupled plasma mass spectrometry. Env. Monitor. Assess., 157(1-4): 347-354.

Lodhi Z H, Akif M, Kalsoom U, 2003. Evaluation of drinking water from different sources in Skardu-Northern area with special reference to heavy metals. J. Chem. Soc. Pak., 25(2): 110-113.

Majidano S A, Khuwahar M Y, 2009. Distribution of heavy metals in the groundwater of Taluka Daur, District Nawabshaw, Sindh, Pakistan, and its impact on human health. J. Chem. Soc. Pak., 31(3): 408-414.

Mastoi G M, Syed G S S, Mohammad Y K, 2008. Assessment of water quality of Manchar lake in Sindh (Pakistan). Env. Monitor. Asses., 141(1-3): 287-296.

Prasad B G, Narayana T S, 2004. Subsurface water quality of different sampling stations with some selected parameters at Machilipatnam Town. Nat. Env. Poll. Tech., 3(1): 47-50.

Rashid S, Yagub M, Afzal H et al., 1996. Evaluation of some heavy metals (Ni, Pb, Cu, Cd, Zn and Cr) from drinking water of Faisalabad City. Prof. Med. J., 3(4): 317-23.

Rehman K, Ashraf S, Rashid U et al., 2013. Comparison of proximate and heavy metal contents of vegetables grown with fresh and wastewater. Pak. J. Bot., 45: 391-400.

Said M, Muhammad T S, Sardar K, 2011. Health risk assessment of heavy metals and their source apportionment in drinking water of Kohistan region, Northern Pakistan. Microcheml. J., 18(2): 334-343.

Santos A, Alonso E, Callejon $\mathrm{M}$ et al.,_2000. Distribution of $\mathrm{Zn}, \mathrm{Cd}, \mathrm{Pb}$ and $\mathrm{Cu}$ metals in groundwater of the Guadiamar river basin. Water Air Soil Poll., 134HYPERLINK. "http://www.springerlink.com/content/00496979/134/1-4/"(1-4): 273-283.

Tariq S R, Munir H S, Shaheen N et al., 2008. Statistical source identification of metals in groundwater exposed to industrial contamination. J. Env. Monito. Assess., 138(1-3): 159-165.

Ullah R, Riffat N M, Abdul Q, 2009. Assessment of groundwater contamination in an industrial city, Sialkot, Pakistan. Afr. J. Env. Sci. Tech., 3(12): 429-446. 